\title{
The Impacts of Young Consumers' Health Values on Functional Beverages Purchase Intentions
}

\author{
Hsiao-Ping Chang ${ }^{1,2}$, Chun-Chieh $\mathrm{Ma}^{3}$ and Han-Shen Chen ${ }^{1,2, *(1)}$ \\ 1 Department of Health Diet and Industry Management, Chung Shan Medical University, No.110, Sec. 1, \\ Jianguo N. Rd. Taichung City 40201, Taiwan; pamela22@csmu.edu.tw \\ 2 Department of Medical Management, Chung Shan Medical University Hospital, No. 110, Sec. 1, Jianguo N. \\ Rd., Taichung City 40201, Taiwan \\ 3 Department of Public Administration and Management, National University of Tainan, Taiwan, No.33, \\ Sec. 2, Shu-Lin St., Tainan 70005, Taiwan; ccma@mail.nutn.edu.tw \\ * Correspondence: allen975@csmu.edu.tw; Tel.: +886-4-2473-0022 (ext. 12225)
}

Received: 24 April 2020; Accepted: 14 May 2020; Published: 16 May 2020

check for updates

\begin{abstract}
Internationally, there is increasing recognition of the importance of proper diet values and habits, a balanced intake of healthy food products, and rates of obesity control encompassing information on fat content and calories. In this context, some beverage manufacturers have shifted to marketing their products as having fewer calories and more functional benefits. This study aims to develop an extended value-attitude-behavior (VAB) research model that includes three constructs, namely, cue to action, self-efficacy, and health orientation, to explore the impacts of university students' health values on their purchase intentions concerning functional beverages. The results indicated that university students' interest in functional beverages was significantly affected by their health values. Besides, both interests in functional beverages and health orientation were significant predictors of purchase intention, while cue to action and self-efficacy were not. Based on these results, enhancing consumers' education about food security is suggested. Furthermore, the findings provide crucial insights for marketing channels, suggesting the beverage industry can target consumers' health values concerning health beverages as the key to purchase intention and attract business by developing practical marketing strategies.
\end{abstract}

Keywords: eating patterns; consumer preferences; health food; self-efficacy; health orientation

\section{Introduction}

According to some studies [1,2], with the gradual increase of chronic civilized diseases, obesity, and cardiovascular diseases all over the world, consumers have started to pay more attention to health, and the promotion of good value is gradually adding visibility to the notion of healthy diets. Without the parents' supervision of diet and lifestyle, being overweight or obese has become prevalent among college students in Taiwan [3]. This encourages businesses to take advantage of business opportunities related to "functional food" and nutrient and dietary supplements.

Every country has different terms and definitions for health food (e.g., "health food" in Taiwan, "food for specified health uses" in Japan, and "functional food" in China). In Taiwan, "health food" refers to food that contains a specific nutrient or one that produces particular health effects, but not offered to the public as treatment or remedy for human diseases. The term "functional beverages" mostly refers to beverages that contain additives to reduce blood lipids, reduce fat absorption, and aid digestion and other body functions.

In 2017, the Industrial Development Bureau, Ministry of Economic Affairs, approved a total of 379 health food items, of which 102 were beverages. Given their popularity, these beverages have a crucial 
role in marketing sales. In Taiwan, for example, functional beverages yield two billion NT dollars in market sales each year, which means they have outsold carbonated drinks and become the largest beverage market. This shows that consumers tend to choose "fewer calories, more function" products. Accordingly, beverages with "healthy food" labels have become the trend in the current packaged beverage market [4]. For these reasons, how to retain customers and attract new ones has become an essential issue for the industry.

Among the models that were proposed by social psychologists in the last few decades to predict and understand human behaviors, the theory of planned behavior (TPB) has gained greater acceptance. $[5,6]$. Yazdanpanah, Forouzani, and Hojjati [7] extended TPB with various variables (e.g., moral standards and self-identity) to investigate Iranian students' intention to purchase organic food. Lorenz, Hartmann, and Simons [8] utilized TPB to explore consumers' plan to buy products with origin labels, and Yadav and Pathak [9] applied it to study consumers' green purchase behavior in developing nations. Wong, $\mathrm{Hsu}$, and Chen [10] utilized extended TPB to explore consumers' attitudes and purchase intentions for suboptimal food.

According to social adaptation theory, values, as an amalgam of social cognitions, enable individuals to adapt to an environment, guiding them to how to act in a particular situation [11,12]. It is subjective and will be formed through the social and psychological development of consumers. Scholars have addressed values to be the most abstract constructs that build attitudes and behaviors $[13,14]$. However, several studies proposed that cost is a more fundamental social cognition than mentality [15], and through the establishment of value, eating habits and behavior might be changed in the long term [16]. A growing number of research studies have used the value-attitude-behavior (VAB) model to analyze consumers' purchase behavior. Honkanen, Verplanken, and Olsen [17] considered moral cognition in their exploration of whether consumers' moral values about the environment and animal welfare affected their choices of organic food. Kang, Jun, and Arendt [18] applied the VAB model to investigate purchase intentions for a low-calorie diet. Jun et al. [16] used the model to study the effects of health value on healthful food selection intention. Although previous studies have addressed similar topics in other countries, we sought to explore the critical factor in college students' consumption of functional beverages in Taiwan. This is the motivation of this study.

The study variables are a cue to action, self-efficacy, and health orientation. They were selected for the following reasons. Among various factors affecting consumer purchase intention, signal to work is a valuable information source as it might influence consumers' health behavior [19-21]. Cue to action refers to the stimulus that urges individuals to take steps, which can be divided into external stimuli and internal stimuli. External stimuli such as media dissemination, interpersonal interaction, advice from family and friends, etc., and internal stimuli such as conscious physical discomfort, symptoms of the disease, etc., all affect whether an individual takes action or not [22,23]. Hanson and Benedict [24] indicated that cue to action has a positive influence on senior adults' food-handling behaviors, promotes healthy behavior, and may also affect purchase intention for functional beverages.

Self-efficacy is a variable commonly seen in previous studies, and it appears in the health belief model in related research. Self-efficacy refers to a person's confidence that he or she has enough power to do something [25]. Several studies have explored self-efficacy and purchase intention. For instance, Milne, Sheeran, and Orbell [26] showed that self-efficacy and purchase intention have a significant relationship, and Yazdanpanah et al. [7] found that self-efficacy has a positive influence on organic food purchase intention.

The third variable, health orientation, is a personal attitude toward health, beliefs, and behavior-it extends to individual concern about health-related issues [27]. De Marchi, Caputo, Nayga, and Banterle [28] demonstrated that levels of engagement in health-related action and food consumption decisions result from one's health orientation. De Boer, McCarthy, Cowan, and Ryan [29] also found that a consumer's health orientation hurts purchase intention for convenience foods.

Above all, this study utilizes the VAB model and considers the three research dimensions of the cue to action, self-efficacy, and health orientation. We aim to determine whether consumers' good 
value affects their interest in functional beverages, as well as whether interest in functional beverages affects purchase intention. We hope that the findings will provide insights for marketing by revealing what consumers care about in their purchasing of functional beverages and thus inspire effective marketing strategies and create more business opportunities for related business organizations.

\section{Materials and Methods}

\subsection{Research Framework}

According to the VAB model, value affects behavior intention through attitude. In this study, the discussion of the relationship between consumers' health value, interest in healthy food, and purchase intention focuses on three constructs: cue to action, self-efficacy, and health orientation. The proposed theoretical framework is shown in Figure 1, and the five hypotheses are below.

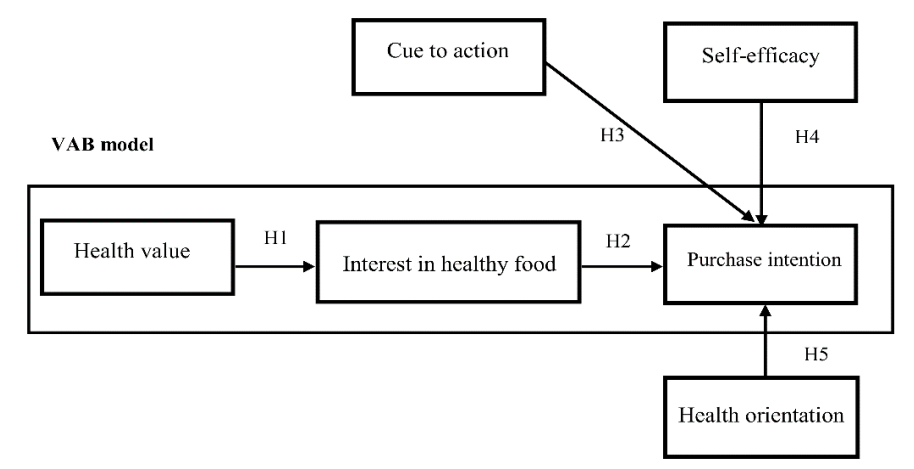

Figure 1. Research framework based on the value-attitude-behavior (VAB) model.

\subsection{Research Hypotheses}

The VAB model has been widely used to understand consumer behavior in the study of social psychology [15]. The underlying meaning of value is a basic standard to guide people's actions. It is subjective and is formed through the social and psychological development of consumers. Attitude is the feeling a person has in carrying out specific behavior, or positive or negative thinking that accompanies the particular action. It is an essential factor to forecast consumer behavior intention [21], and it influences individual behavior [30]. Tudoran, Olsen, and Dopico [31] argued that value affects consumer behavior through attitude. This study utilizes health value, interest in healthy food, and purchase intention as the theoretical basis for the VAB model.

Purchase intention means the possibility of a consumer buying a product, and a higher purchase intention means a higher rate of purchasing the product [32,33]. Purchase intention is often considered an indicator of subsequent purchase and can be used to predict purchasing behavior. Lessa et al. [34] found that when consumers pay more attention to health issues, they are willing to give up high-fat or high-calorie foods for the sake of their health. Consumers' concerns about food quality and personal hygiene have been related to them to acquire information about the quality of food, particularly at the purchase decision stage of the buying process [35]. Kang et al. [18] found that consumers choose healthy food to keep healthy and fit, and they make choices for a healthy diet using individual subjective knowledge. Food safety often linked to human health and food quality, and it plays a vital role in consumer choices is represented (e.g., expiry dates and the presence of specific ingredients and additives) [36]. Consumers' purchase intentions become more potent when they find that eating healthy food can help them achieve their health goals (e.g., maintaining or losing weight) [37].

Tudoran et al. [31] described health value as the extent to which a person cares about his or her health status, and noted that consumers' health value is related to product function and purchase intention. Jun, Kang, and Arendt [38] found that consumers set the goal of achieving health, so there 
will be different degrees of values. Moreover, health value has a positive influence on health behavior and attitude toward health products [39]. Accordingly, we hypothesize that:

Hypothesis (H1). Health value has a positive influence on interest in functional beverages.

Roininen, Lähteenmäki, and Tuorila [40] defined "interest in healthy food" as an interest in energy-reduced foods such as low-fat, low-calorie, and sugar-free foods. Consumers think that these can help them maintain or achieve better health, so they feel less guilty about eating a healthy diet compared to other food [41]. Tudoran, Scholderer, and Brunsø [42] indicated that the higher the emphasis consumers place on health, the more likely they are to choose healthy foods [43]. Vázquez, Curia, and Hough [44] showed that consumers who have a healthy life are more likely to be interested in continuing to eat healthy foods. The discussion results into the following hypotheses:

Hypothesis (H2). Interest in healthy food has a positive influence on purchase intention.

Cues to action include internal cues (e.g., disease situation) and extrinsic cues (e.g., public media report, interpersonal interaction, and health check results) that prompt the consumer to engage in health behavior [19]. A cue to action can also be a motivation behind a person's health behavior [20]. Hanson and Benedict [24] found that cue to action has a positive effect on consumer behavior in handling food security and promoting the healthy practice. Accordingly, we hypothesize that:

Hypothesis (H3). Cue to action has a positive influence on purchase intention.

Bandura [18] defined self-efficacy as the confidence that one can do something. Self-efficacy has no relationship with personal skill; instead, it is related to self-judgment of the extent of one's ability. Self-efficacy can determine individual behavior in specific situations, ways of thinking, and emotional reactions. Yazdanpanah et al. [7] found that self-efficacy positively influences purchase intention for organic food, and Milne et al. [26] showed that self-efficacy is one of the critical factors that affect purchase intention. The discussion results into the following hypotheses:

Hypothesis (H4). Self-efficacy has a positive influence on purchase intention.

Dutta et al. [27] defined health orientation as attitudes, beliefs, behaviors, and care about health-related issues concerning personal health. People have an incentive to engage in the healthy practice for the sake of their health [45]. Previous studies showed that health orientation influences people's levels of food consumption related to health promotion and decision making $[17,46]$. The discussion results into the following hypotheses:

Hypothesis (H5). Health orientation has a positive influence on purchase intention.

\subsection{Questionnaire Design}

The design of questionnaire items stemmed from a review of pertinent literature and involved the use of a 7-point Likert scale, with 7 representing Strongly Agree and 1 representing Strongly Disagree. Details about the source of the questionnaire items are highlighted in Table 1. 
Table 1. Constructs/variables and corresponding measuring statements included in the questionnaire.

\begin{tabular}{|c|c|c|c|}
\hline Construct/Variable & $\begin{array}{l}\text { Number of } \\
\text { Statements }\end{array}$ & Measuring Items & Sources of Adoption \\
\hline Health value & 3 & $\begin{array}{l}\text { 1. I often think about my health. } \\
\text { 2. I think of myself as a person who is interested in healthful food. } \\
\text { 3. Good health is important to me. }\end{array}$ & Tudoran et al. [31] \\
\hline Interest in healthy food & 15 & $\begin{array}{l}\text { 1. I think buying functional beverages is a good idea. } \\
\text { 2. I think buying functional beverages is very important. } \\
\text { 3. I think buying functional beverages is good. } \\
\text { 4. I think buying functional beverages is wise. } \\
\text { 5. I think buying functional beverages can regulate blood lipids. } \\
6 . \quad \text { I think buying functional beverages can regulate blood sugar. } \\
\text { 7. I think buying functional beverages can improve osteoporosis. } \\
\text { 8. I think buying functional beverages can improve the immune system. } \\
\text { 9. I think buying functional beverages can improve gastrointestinal function. } \\
\text { 10. I think buying functional beverages can protect the liver. } \\
\text { 11. I think buying functional beverages can regulate blood pressure. } \\
\text { 12. I think buying functional beverages has a body fat lowering effect. } \\
\text { 13. I think buying functional beverages can help improve allergies. } \\
\text { 14. It is essential to have functional beverages every day. } \\
\text { 15. I believe that buying functional beverages can keep my body in shape. }\end{array}$ & Tudoran et al. [31] \\
\hline Cue to action & 3 & $\begin{array}{l}\text { 1. I read about functional beverages and understand that drinking functional beverages can } \\
\text { improve your body function. } \\
\text { 2. There are lectures on functional beverages at my university. } \\
\text { 3. There are advertisements or articles posted on functional beverages at my university. }\end{array}$ & Vassallo et al. [20] \\
\hline Self-efficacy & 4 & $\begin{array}{l}\text { 1. I have set clear goals to improve my health. } \\
\text { 2. I have achieved my goals to improve my health. } \\
\text { 3. I am trying to improve my health. } \\
\text { 4. I think I have control and understand my health. }\end{array}$ & $\begin{array}{l}\text { Şimşekoğlu and Lajunen [47], Lee, } \\
\text { Hwang, Hawkins, and Pingree [48]. }\end{array}$ \\
\hline Health orientation & 3 & $\begin{array}{l}\text { 1. I'm interested in information on functional beverages. } \\
\text { 2. I often pay attention to functional beverages. } \\
\text { 3. I often read information about functional beverages. }\end{array}$ & Ng, Kankanhalli, and Xu [49] \\
\hline Purchase intention & 5 & $\begin{array}{l}\text { 1. If functional beverages are available, I will try to buy one. } \\
\text { 2. If I choose again, I will still buy functional beverages. } \\
3 . \quad \text { I try to buy functional beverages because they are the best choice. } \\
\text { 4. I think I am a loyal customer of functional beverages. } \\
\text { 5. I'm happy to buy functional beverages. }\end{array}$ & $\begin{array}{l}\text { Lee, Hsu, Han, and Kim [50], } \\
\text { Yazdanpanah et al. [7]. }\end{array}$ \\
\hline
\end{tabular}




\subsection{Sample Size and Composition}

The participants were students from 10 colleges (undergraduate and graduate) in central Taiwan. We chose college students because they have higher homogeneity, such as no significant differences in age and education among 18-30 year olds. This group is known to be active both in society and on the Internet and, thus, quite likely to know about functional beverages. Face-to-face interviews, each of which took 20-25 minutes, were done in the fall of 2017 to gather the data, and no intermediaries were involved. Responses were carefully checked for completeness, and students were informed that they could refuse to participate or refrain from answering any particular questions that they considered overly sensitive. Students were not paid for their participation, and replacements were found for those declining to participate. The data was gathered mainly on campus, either in the classroom or at other campus locations. In total, we received 261 responses. However, only 213 responses were considered for analysis after invalid responses were removed.

As Table 2 shows, the majority of the participants were female (74.65\%). A large percentage were seniors (43.66\%), and the most common purchase frequency was 1-2 times a week (38.50\%).

Table 2. Sample characteristics.

\begin{tabular}{|c|c|c|c|c|c|c|c|}
\hline$N=213$ & Item & $N$ & Percentage & Variable & Item & $N$ & Percentage \\
\hline \multirow{3}{*}{ Gender } & Male & 54 & $25.35 \%$ & \multirow{8}{*}{$\begin{array}{c}\text { The frequency } \\
\text { of buying } \\
\text { functional } \\
\text { beverages }\end{array}$} & Never & 24 & $11.27 \%$ \\
\hline & Female & 159 & $74.65 \%$ & & 1-2 times a week & 82 & $38.50 \%$ \\
\hline & Freshman & 33 & $15.49 \%$ & & 3-4 times a week & 18 & $8.45 \%$ \\
\hline \multirow{5}{*}{ Level } & Sophomore & 32 & $15.02 \%$ & & $\begin{array}{c}\text { More than } 5 \text { times } \\
\text { a week }\end{array}$ & 5 & $2.35 \%$ \\
\hline & Junior & 31 & $14.55 \%$ & & 1-2 times a month & 55 & $25.82 \%$ \\
\hline & Senior & 93 & $43.66 \%$ & & $\begin{array}{c}1-2 \text { times } \\
\text { semi-yearly }\end{array}$ & 22 & $10.33 \%$ \\
\hline & Graduate student & 22 & $10.33 \%$ & & 1-2 times a year & 7 & $3.29 \%$ \\
\hline & $\begin{array}{c}\text { Other (Department of } \\
\text { Medicine) }\end{array}$ & 2 & $0.94 \%$ & & & & \\
\hline
\end{tabular}

\subsection{Statistical Analysis}

The theoretical framework was analyzed using SPSS (Statistical Package for Social Science) (IBM Corp.: New York, NY, USA) and AMOS (Analysis of Moment Structure) version 21 (IBM Corp.: New York, NY, USA). Two SEM study models were investigated in a study [51]. The two models, namely a measurement model and a structural model, were used to test for validity and reliability, and to test for model fit and hypothesis testing, respectively.

\section{Results}

\subsection{Measurement Model: Reliability and Validity}

Nunnally [51] noted that there is high internal consistency when Cronbach's $\alpha$ is higher than 0.7, and the measure should be rejected if Cronbach's $\alpha$ is lower than 0.35 . Further, if the factor loading in each construct is higher than 0.5 , the construct has construct validity [52]. For the following questionnaire items, Cronbach's $\alpha$ did not reach the standard of 0.5 . The questions were deleted: concerning the health value, Item 2 "I think of myself as a person who is interested in healthy food" and Item 5 "I'm not concerned about the health-related consequences of what I eat"; concerning self-efficacy, Item 25 "It is easy for me to buy functional beverages", Item 26 "Drinking functional beverages is under my control", and Item 27 "I believe that drinking functional beverages has a positive impact on my health." Since most of the questionnaire items had a Cronbach's $\alpha$ higher than or close to 0.7, there was high reliability. Furthermore, the average variance extracted (AVE) and construct reliability (CR) also met the criterion. The details of reliability and convergent validity are outlined in Table 3. Means, standard deviations, and correlations among the constructs are presented in Table 4. 
Table 3. Results of the factor loading, reliability, and validity.

\begin{tabular}{|c|c|c|c|c|c|}
\hline Constructs & Items & Factor Loading & Cronbach's $\alpha$ & CR & AVE \\
\hline \multirow{3}{*}{ Health value (HA) } & HA1 & 0.578 & \multirow{3}{*}{0.825} & \multirow{3}{*}{0.842} & \multirow{3}{*}{0.648} \\
\hline & HA2 & 0.921 & & & \\
\hline & HA3 & 0.873 & & & \\
\hline \multirow{15}{*}{ Interest in healthy food (IHF) } & IHF1 & 0.617 & \multirow{15}{*}{0.941} & \multirow{15}{*}{0.923} & \multirow{15}{*}{0.522} \\
\hline & IHF2 & 0.605 & & & \\
\hline & IHF3 & 0.608 & & & \\
\hline & IHF4 & 0.581 & & & \\
\hline & IHF5 & 0.825 & & & \\
\hline & IHF6 & 0.850 & & & \\
\hline & IHF7 & 0.804 & & & \\
\hline & IHF8 & 0.805 & & & \\
\hline & IHF9 & 0.730 & & & \\
\hline & IHF10 & 0.813 & & & \\
\hline & IHF11 & 0.868 & & & \\
\hline & IHF12 & 0.730 & & & \\
\hline & IHF13 & 0.727 & & & \\
\hline & IHF14 & 0.595 & & & \\
\hline & IHF15 & 0.567 & & & \\
\hline \multirow{3}{*}{ Cue to action (CA) } & CA1 & 0.549 & \multirow{3}{*}{0.802} & \multirow{3}{*}{0.823} & \multirow{3}{*}{0.619} \\
\hline & CA2 & 0.811 & & & \\
\hline & CA3 & 0.948 & & & \\
\hline \multirow{4}{*}{ Self-efficacy (SE) } & SE1 & 0.874 & \multirow{4}{*}{0.860} & \multirow{4}{*}{0.859} & \multirow{4}{*}{0.606} \\
\hline & SE2 & 0.771 & & & \\
\hline & SE3 & 0.724 & & & \\
\hline & SE4 & 0.735 & & & \\
\hline \multirow{3}{*}{ Health orientation (HO) } & HO1 & 0.805 & \multirow{3}{*}{0.890} & \multirow{3}{*}{0.893} & \multirow{3}{*}{0.737} \\
\hline & $\mathrm{HO} 2$ & 0.935 & & & \\
\hline & $\mathrm{HO} 3$ & 0.830 & & & \\
\hline \multirow{5}{*}{ Purchase intention (PI) } & PI1 & 0.753 & \multirow{5}{*}{0.924} & \multirow{5}{*}{0.909} & \multirow{5}{*}{0.668} \\
\hline & PI2 & 0.884 & & & \\
\hline & PI3 & 0.872 & & & \\
\hline & PI4 & 0.781 & & & \\
\hline & PI5 & 0.787 & & & \\
\hline
\end{tabular}

Note. $\mathrm{CR}=$ Composite reliability, AVE = Average variance extracted.

Table 4. Means, standard deviations, and correlations of constructs.

\begin{tabular}{ccccccccc}
\hline Construct & Mean & S.D. & $\mathbf{1}$ & $\mathbf{2}$ & $\mathbf{3}$ & $\mathbf{4}$ & $\mathbf{5}$ & $\mathbf{6}$ \\
\hline 1. Health value (HA) & 5.96 & 0.92 & 1.00 & & & & & \\
2. Interest in healthy food (IHF) & 5.12 & 1.30 & 0.22 & 1.00 & & & & \\
3. Cue to action (CA) & 4.39 & 1.32 & 0.27 & 0.35 & 1.00 & & & \\
4. Self-efficacy (SE) & 4.90 & 0.96 & 0.38 & 0.32 & 0.30 & 1.00 & & \\
5. Health orientation (HO) & 5.34 & 1.08 & 0.47 & 0.45 & 0.31 & 0.40 & 1.00 & \\
6. Purchase intention (PI) & 5.72 & 1.16 & 0.50 & 0.44 & 0.39 & 0.33 & 0.48 & 1.00 \\
\hline
\end{tabular}

Note. S.D. = Standard Deviation.

\subsection{Structural Model: Goodness of Fit Statistics and Hypothesis Testing}

A goodness of fit test conducted on the theoretical framework yielded the following results, which lie within the acceptable limits $\left(x^{2}=242.762, x^{2} / d f=2.352\right.$, goodness of fit index (GFI) $=0.916$, Tucker Lewis index $(\mathrm{TLI})=0.927$, incremental fit index $(\mathrm{IFI})=0.954$, root mean square error of approximation $($ RMSEA $)=0.046)$. All other fit indices were above the recommended criteria [53]. As a result, all indices provided evidence of an acceptable measurement model (Table 5). 
Table 5. Summary of goodness-of-fit indices for the structural models.

\begin{tabular}{ccccccc}
\hline Model & $x^{2}$ & $x^{2} / \mathbf{d f}$ & GFI & TLI & RMSEA & IFI \\
\hline Structural model & 242.762 & 2.352 & 0.916 & 0.927 & 0.046 & 0.954 \\
Recommended value & N/A & $\leq 3.00$ & $\geq 0.90$ & $\geq 0.90$ & $<0.08$ & $\geq 0.90$ \\
\hline
\end{tabular}

Note. goodness of fit index $(\mathrm{GFI})=0.916$; Tucker Lewis index $(\mathrm{TLI})=0.927$; incremental fit index (IFI) = 0.954; root mean square error of approximation (RMSEA) $=0.046$.

\subsection{Results of SEM}

The results of the participants' purchase intentions concerning functional beverages are shown in Figure 2. Healthy value had a positive influence on interest in functional beverages $(\beta=0.209, p<0.05)$, and interest in healthy food had a positive significant influence on purchase intention $(\beta=0.300$, $p<0.001)$. Health orientation had a positive significant influence on purchase intention $(\beta=0.693$, $p<0.001)$. However, neither cue to action $(\beta=-0.032, p>0.05)$ nor self-efficacy $(\beta=0.065, p>0.05)$ had a positive influence on purchase intention. Based on these findings, $\mathrm{H} 1, \mathrm{H} 2$, and $\mathrm{H} 5$ were supported, but $\mathrm{H} 3$ and $\mathrm{H} 4$ were not.

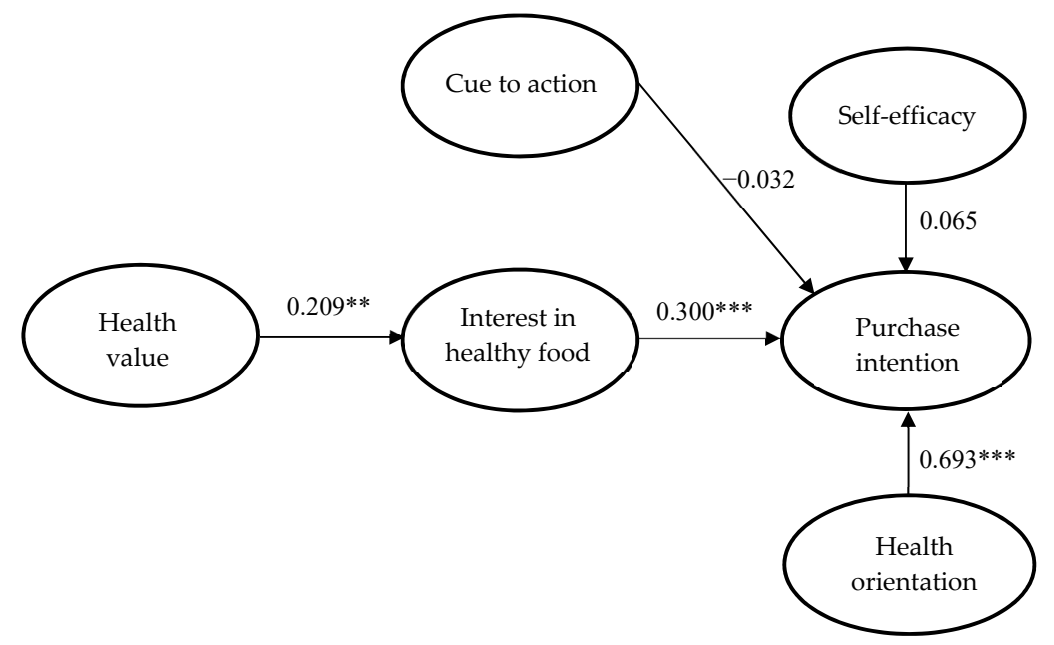

Figure 2. Results of SEM. Note. ${ }^{* *} p<0.01 ;^{* * *} p<0.001$

\section{Discussion}

A summary of the verification of the hypotheses made in this study is shown in Table 6 . The results of this study supported H1, given that the participants' interest in healthy food was significantly affected by the health value. It appeared that the participants paid much attention to their health and were interested in functional beverages with the "little green label" (a green label attached to healthy products certifying specific health efficacy in Taiwan). This finding is in agreement with Olsen [30] results showing that there is a strong relationship between consumers' health value and attitude in healthy products.

Table 6. Summary of hypothesis verification.

\begin{tabular}{ccc}
\hline Hypothesis & Content & Verification \\
\hline H1 & Health value has a positive influence on interest in functional beverages. & Supported \\
H2 & Interest in healthy food has a positive influence on purchase intention. & Supported \\
H3 & Cue to action has a positive influence on purchase intention. & Rejected \\
H4 & Self-efficacy has a positive influence on purchase intention. & Rejected \\
H5 & Health orientation has a positive influence on purchase intention. & Supported \\
\hline
\end{tabular}

With regard to $\mathrm{H} 2$, interest in healthy food and purchase intention appeared to be highly related in the sense that as interest in functional beverages rose, so did purchase intention. This result clearly 
supports the notion that the more concern consumers show, the higher the possibility is that they will choose healthier products [42,43].

However, contrary to $\mathrm{H} 3$ and $\mathrm{H} 4$, the analysis showed that neither cue to action nor self-efficacy was a significant predictor of purchase intention. This might indicate that for consumers, extrinsic cues (e.g., advertisements, lectures) are not a critical factor in purchase intention for functional beverages. These findings are not in accord with the results of previous studies [7]. Strecher et al. [54] results were showing that strong relationships between self-efficacy and health behavior change and maintenance. Matthews, Doerr, and Dworatzek [55] results were showing that higher self-efficacy, and more cue to action toward healthier eating. Warziski et al. [56] showed that self-efficacy for controlling eating in a set of circumstances increased with weight loss and was correlated to the degree of weight loss. From the findings on cue to action and self-efficacy, we found that the participants had insufficient or quite different cognition about functional beverages. Analyze the reason and it may be related to nearly $75 \%$ of the female respondents in this study, they tended to consider drinks as unhealthy.

Lastly, health orientation had a positive influence on purchase intention (H5). This is in line with De Marchi et al.'s [28] results showing that health-related actions and food consumption decisions resulted from health orientation. The more consumers understand information about functional beverages, the higher their purchase intentions might be.

\section{Conclusions}

\subsection{Conclusions}

The results of this study show that the health value, interest in healthy food, and health orientation have a significant influence on consumers' willingness to purchase health products. This means that the more consumers care about their health, the healthier life they tend to have, and the more robust products they choose. Thus, this study suggests that manufacturers can formulate a sound marketing strategy to motivate consumers' health awareness and increase their interest in healthy food. For example, slogans or advertisements might ask, "Is the beverage you are drinking healthy?" or "Are you healthy?". Beverages manufacturers might also feature information about health value on product packaging to arouse consumers' interest in healthy food. Once these strategies succeed in motivating consumers to pay attention to their health, the consumers will be more interested in health products and have greater purchase intention.

\subsection{Management Implications}

From the findings on cue to action and self-efficacy, we found that the participants had insufficient or quite different cognition about functional beverages. They tended to consider drinks as unhealthy. Yet foods or beverages that are certified as having a health function may help improve their health. To eliminate the "unhealthy" perception of functional beverages, this study suggests that the government should promote the benefits of drinking water or the significance and importance of health labels such as the "little green label." It is necessary to establish common knowledge about beverages and change people's perceptions by holding food safety education briefings. Another suggestion is to promote the meaning of relevant certifications through public media. Once consumers have accurate, detailed knowledge about how to identify related healthy labels, their purchase intention may increase.

In recent years, consumers have increasingly been paying attention to healthy diets, and their health values, interest in health food, and health orientation affect their willingness to purchase healthy products. Consumers who care more about health tend to have healthier lives and choose more robust products. Furthermore, related industries can keep upgrading the health functions of their products, for example, to regulate blood pressure, blood lipids, and blood sugar. Moreover, associated industries may apply healthy food labels or certification to highlight how healthy their products are and explain the product specifications so that consumers may choose functional beverages according to their own needs and increase their purchase intention. 


\subsection{Research Limitations and Further Research}

This study only focused on college students in central Taiwan, and the sample was not large enough to represent all university students' cognition and behavior on functional beverages. Additionally, since most of the participants were female, the results may not accurately represent how men think about functional beverages. Therefore, more extensive research (e.g., with an expanded investigation area and more excellent age range) is needed in the future. Other statistical variables (e.g., monthly income) or other variables (e.g., personality, lifestyle) may be added as well, to explore whether they affect a consumer's purchase intention for functional beverages, making the research framework more complete.

Author Contributions: Writing—review, analysis, and interpretation of data, H.-P.C.; Writing-review and editing, C.-C.M.; Writing—review, editing, and project administration, H.-S.C. All authors have read and agreed to the published version of the manuscript.

Funding: This research received no external funding.

Conflicts of Interest: The author declares no conflict of interest.

\section{References}

1. Jones, C.S. Taking up space? How customers react to health information and health icons on restaurant menus. J. Foodserv. Bus. Res. 2009, 12, 344-363. [CrossRef]

2. Yach, D.; Stuckler, D.; Brownell, K.D. Epidemiologic and economic consequences of the global epidemics of obesity and diabetes. Nat. Med. 2006, 12, 62-66. [CrossRef]

3. Hsieh, H.-H.; Chang, C.-M.; Liu, L.-W.; Huang, H.-C. The relative contribution of dietary habits, leisure-time exercise, exercise attitude, and body mass index to self-rated health among college students in Taiwan. Int. J. Environ. Res. Public Health 2018, 15, 967. [CrossRef]

4. Temple, J.L.; Ziegler, A.M.; Epstein, L.H. Influence of price and labeling on energy drink purchasing in an experimental convenience store. J. Nutr. Educ. Behav. 2016, 48, 54-59. [CrossRef]

5. Maichum, K.; Parichatnon, S.; Peng, K.-C. Application of the extended theory of planned behavior model to investigate purchase intention of green products among Thai consumers. Sustainability 2016, 8, 1077. [CrossRef]

6. Zhang, L.; Chen, L.; Wu, Z.; Zhang, S.; Song, H. Investigating young consumers' purchasing intention of green housing in China. Sustainability 2018, 10, 1044. [CrossRef]

7. Yazdanpanah, M.; Forouzani, M.; Hojjati, M. Willingness of Iranian young adults to eat organic foods: Application of the health belief model. Food Qual. Prefer. 2015, 41, 75-83. [CrossRef]

8. Lorenz, B.A.; Hartmann, M.; Simons, J. Impacts from region-of-origin labeling on consumer product perception and purchasing intention-causal relationships in a TPB based model. Food Qual. Prefer. 2015, 45, 149-157. [CrossRef]

9. Yadav, R.; Pathak, G.S. Determinants of consumers' green purchase behavior in a developing nation: Applying and extending the theory of planned behavior. Ecol. Econ. 2017, 134, 114-122. [CrossRef]

10. Wong, S.L.; Hsu, C.C.; Chen, H.S. To buy or not to buy? Consumer attitudes and purchase intentions for suboptimal food. Int. J. Environ. Res. Public Health 2018, 15, 1431. [CrossRef] [PubMed]

11. Homer, P.M.; Kahle, L.R. A structural equation test of the value-attitude-behavior hierarchy. J. Pers. Soc. Psychol. 1988, 54, 638. [CrossRef]

12. Kahle, L.R. Social values and consumer behavior: Research from the list of values. In The Psychology of Values: The Ontario Symposium; Lawrence Erlbaum Associates: Mahwah, NJ, USA, 1996; Volume 8, pp. 135-151.

13. Chryssohoidis, G.M.; Krystallis, A. Organic consumers' personal values research: Testing and validating the list of values (LOV) scale and implementing a value-based segmentation task. Food Qual. Prefer. 2005, 16, 585-599. [CrossRef]

14. Shin, Y.H.; Moon, H.; Jung, S.E.; Severt, K. The effect of environmental values and attitudes on consumer willingness to pay more for organic menus: A value-attitude-behavior approach. J. Hosp. Tour. Manag. 2017, 33, 113-121. [CrossRef]

15. Rokeach, M. The Nature of Human Values; The Free press: New York, NY, USA, 1973. 
16. Van Doorn, J.; Verhoef, P.C. Willingness to pay for organic products: Differences between virtue and vice foods. Int. J. Res. Mark. 2011, 28, 167-180. [CrossRef]

17. Honkanen, P.; Verplanken, B.; Olsen, S.O. Ethical values and motives driving organic food choice. J. Consumer Behav. 2006, 5, 420-430. [CrossRef]

18. Kang, J.; Jun, J.; Arendt, S.W. Understanding customers' healthy food choices at casual dining restaurants: Using the value-attitude-behavior model. Int. J. Hosp. Manag. 2015, 48, 12-21. [CrossRef]

19. Luquis, R.R.; Kensinger, W.S. Applying the health belief model to assess prevention services among young adults. Int. J. Health Promot. Educ. 2019, 57, 37-47. [CrossRef]

20. Vassallo, M.; Saba, A.; Arvola, A.; Dean, M.; Messina, F.; Winkelmann, M.; Shepherd, R. Willingness to use functional breads. Applying the health belief model across four European countries. Appetite 2009, 52, 452-460. [CrossRef]

21. Mukhtar, S. Mental health and emotional impact of COVID-19: Applying health belief model for medical staff to general public of Pakistan. Brain. Behav. Immun. 2020. [CrossRef]

22. Osterberg, L.; Blaschke, T. Adherence to medication. New Engl. J. Med. 2005, 353, 487-497. [CrossRef]

23. Gallant, M.P.; Spitze, G.D.; Prohaska, T.R. Help or hindrance? How family and friends influence chronic illness self-management among older adults. J. Aging. Res. 2007, 29, 375-409. [CrossRef]

24. Hanson, J.A.; Benedict, J.A. Use of the health belief model to examine older adults' food-handling behaviors. J. Nutr. Educ. Behav. 2002, 34, S25-S30. [CrossRef]

25. Bandura, A. Social Foundations of Thought and Action: A Social Cognitive Theory; Prentice-Hall Inc.: Upper Saddle River, NJ, USA, 1986.

26. Milne, S.; Sheeran, P.; Orbell, S. Prediction and intervention in health-related behavior: A meta-analytic review of protection motivation theory. J. Appl. Soc. Psychol. 2000, 30, 106-143. [CrossRef]

27. Dutta, M.; Bodie, G.; Basu, A. Health disparity and the racial divide among the nation's youth: Internet as an equalizer? In Learning Race and Ethnicity: Youth and Digital Media; MIT Press: Cambridge, MA, USA, 2008.

28. De Marchi, E.; Caputo, V.; Nayga, R.M.; Banterle, A. Time preferences and food choices: Evidence from a choice experiment. Food Policy. 2016, 62, 99-109. [CrossRef]

29. De Boer, M.; McCarthy, M.; Cowan, C.; Ryan, I. The influence of lifestyle characteristics and beliefs about convenience food on the demand for convenience foods in the Irish market. Food Qual. Prefer. 2004, 15, 155-165. [CrossRef]

30. Teng, Y.M.; Wu, K.S.; Huang, D.M. The influence of green restaurant decision formation using the VAB model: The effect of environmental concerns upon intent to visit. Sustainability 2014, 6, 8736-8755. [CrossRef]

31. Tudoran, A.; Olsen, S.O.; Dopico, D.C. The effect of health benefit information on consumers health value, attitudes and intentions. Appetite 2009, 52, 568-579. [CrossRef]

32. Schiffman, L.G.; Kanuk, L.L. Consumer Behavior, 7th ed.; Prentice Hall: New York, NY, USA, 2000.

33. Naylor, R.W.; Lamberton, C.P.; West, P.M. Beyond the "like" button: The impact of mere virtual presence on brand evaluations and purchase intentions in social media settings. J. Mark. 2012, 76, 105-120. [CrossRef]

34. Lessa, K.; Zulueta, A.; Esteve, M.J.; Frigola, A. Study of consumer perception of healthy menus at restaurants. Food Qual. Prefer. 2017, 55, 102-106. [CrossRef]

35. Ingrassia, M.; Bacarella, S.; Columba, P.; Altamore, L.; Chironi, S. Traceability and labelling of food products from the consumer perspective. Chem. Eng. Trans. 2017, 58, 865-870.

36. Banterle, A.; Cavaliere, A.; Ricci, E.C. Food labelled information: An empirical analysis of consumer preferences. Int. J. Food Syst. Dyn. 2012, 3, 156-170.

37. Jun, J.; Kang, J.; Arendt, S.W. The effects of health value on healthful food selection intention at restaurants: Considering the role of attitudes toward taste and healthfulness of healthful foods. Int. J. Hosp. Manag. 2014, 42, 85-91. [CrossRef]

38. Ghazali, E.; Soon, P.C.; Mutum, D.S.; Nguyen, B. Health and cosmetics: Investigating consumers' values for buying organic personal care products. J. Retail. Consum. Serv. 2017, 39, 154-163. [CrossRef]

39. Olsen, S.O. Understanding the relationship between age and seafood consumption: The mediating role of attitude, health involvement and convenience. Food. Qual. Prefer. 2003, 14, 199-209. [CrossRef]

40. Roininen, K.; Lähteenmäki, L.; Tuorila, H. Quantification of consumer attitudes to health and hedonic characteristics of foods. Appetite 1999, 33, 71-88. [CrossRef] [PubMed]

41. Roininen, K. Evaluation of Food Choice Behavior: Development and Validation of Health and Taste Attitude Scales. Ph.D. Thesis, University of Helsinki, Helsinki, Finland, 2001. 
42. Tudoran, A.A.; Scholderer, J.; Brunsø, K. Regulatory focus, self-efficacy and outcome expectations as drivers of motivation to consume healthy food products. Appetite 2012, 59, 243-251. [CrossRef]

43. Kim, H.J.; Park, J.; Kim, M.J.; Ryu, K. Does perceived restaurant food healthiness matter? Its influence on value, satisfaction and revisit intentions in restaurant operations in South Korea. Int. J. Hosp. Manag. 2013, 33, 397-405. [CrossRef]

44. Vázquez, M.B.; Curia, A.; Hough, G. Sensory descriptive analysis, sensory acceptability and expectation studies on biscuits with reduced added salt and increased fiber. J. Sens. Stud. 2009, 24, 498-511. [CrossRef]

45. Olsen, S.O.; Scholderer, J.; Brunsø, K.; Verbeke, W. Exploring the relationship between convenience and fish consumption: A cross-cultural study. Appetite 2007, 49, 84-91. [CrossRef]

46. Geeroms, N.; Verbeke, W.; Van Kenhove, P. Consumers' health-related motive orientations and ready meal consumption behaviour. Appetite 2008, 51, 704-712. [CrossRef]

47. Şimşekoğlu, Ö.; Lajunen, T. Social psychology of seat belt use: A comparison of theory of planned behavior and health belief model. Transp. Res. Part. F. Traffic Psychol. Behav. 2008, 11, 181-191. [CrossRef]

48. Lee, S.Y.; Hwang, H.; Hawkins, R.; Pingree, S. Interplay of negative emotion and health self-efficacy on the use of health information and its outcomes. Commun. Res. 2008, 35, 358-381.

49. Ng, B.Y.; Kankanhalli, A.; Xu, Y.C. Studying users' computer security behavior: A health belief perspective. Decis. Support Syst. 2009, 46, 815-825. [CrossRef]

50. Lee, J.S.; Hsu, L.T.; Han, H.; Kim, Y. Understanding how consumers view green hotels: How a hotel's green image can influence behavioural intentions. J. Sustain. Tour. 2010, 18, 901-914. [CrossRef]

51. Nunnally, J. Psychometric Theory; McGraw-Hill: New York, NY, USA, 1978.

52. Fornell, C.; Larcker, D. Evaluating structural equation models with unobservable variables and measurement error. J. Mark. Res. 1981, 18, 39-50. [CrossRef]

53. Bagozzi, R.P.; Yi, Y. On the evaluation of structural equation models. J. Acad. Mark. Sci. 1998, 16, 74-94. [CrossRef]

54. Strecher, V.J.; DeVellis, B.M.; Becker, M.H.; Rosenstock, I.M. The role of self-efficacy in achieving healthy behavior change. Health Educ. Quart. 1986, 13, 73-92. [CrossRef]

55. Matthews, J.I.; Doerr, L.; Dworatzek, P. University students intend to eat better but lack coping self-efficacy and knowledge of dietary recommendations. J. Nutr. Educ. Behav. 2016, 48, 12-19. [CrossRef]

56. Warziski, M.T.; Sereika, S.M.; Styn, M.A.; Music, E.; Burke, L.E. Changes in self-efficacy and dietary adherence: The impact on weight loss in the PREFER study. J. Behav. Med. 2008, 31, 81-92. [CrossRef] 